\title{
Use of negative binomial distribution to describe the presence of Anisakis in Thyrsites atun
}

\author{
Uso de distribuição binomial negativa para descrever a presença de Anisakis em Thyrsites atun \\ Patricio Peña-Rehbein ${ }^{1 *}$; Patricio De los Ríos-Escalante²
}

${ }^{1}$ Escuela de Medicina Veterinaria, Facultad de Recursos Naturales, Universidad Católica de Temuco

${ }^{2}$ Escuela de Ciencias Ambientales, Facultad de Recursos Naturales, Universidad Católica de Temuco

Received June 14, 2011

Accepted October 26, 2011

\begin{abstract}
Nematodes of the genus Anisakis have marine fishes as intermediate hosts. One of these hosts is Thyrsites atun, an important fishery resource in Chile between 38 and $41^{\circ} \mathrm{S}$. This paper describes the frequency and number of Anisakis nematodes in the internal organs of Thyrsites atun. An analysis based on spatial distribution models showed that the parasites tend to be clustered. The variation in the number of parasites per host could be described by the negative binomial distribution. The maximum observed number of parasites was nine parasites per host. The environmental and zoonotic aspects of the study are also discussed.
\end{abstract}

Keywords: Nematode, Anisakis, Thyrsites atun, negative binomial distribution.

\section{Resumo}

Nematóides do gênero Anisakis têm nos peixes marinhos seus hospedeiros intermediários. Um desses hospedeiros é Thyrsites atun, um importante recurso pesqueiro no Chile entre 38 e $41^{\circ} \mathrm{S}$. Este artigo descreve a freqüência e o número de nematóides Anisakis nos órgãos internos de Thyrsites atun. Uma análise baseada em modelos de distribuição espacial demonstrou que os parasitos tendem a ficar agrupados. A variação numérica de parasitas por hospedeiro pôde ser descrita por distribuição binomial negativa. O número máximo observado de parasitas por hospedeiro foi nove. Os aspectos ambientais e zoonóticos desse estudo também serão discutidos.

Palavras-chave: Nematóide, Anisakis, Thyrsites atun, distribuição binomial negativa.

The snake mackerel (Thyrsites atun) is a carnivorous fish that feeds primarily on schooling marine animals, including Euphausiacea in oceanic areas and squid (Loligo gahi) and small fish, such as anchovies (Engraulis ringens), sardines (Strangomera bentincki), and mote sculpins (Normanichthys crockeri), in neritic areas (DUARTE et al., 2007). The presence of parasites can reflect past and present relationships with their hosts, such as trophic relationships, phylogenetic affinities and migrations (RODRIGUEZ; GEORGE-NASCIMENTO, 1996). Several previous studies found that the stomach and intestines of demersal fish are frequently infected by nematodes and digeneans. More species and more parasitized individuals are found in demersal fish than in species with pelagic habits (MUNOZZ; OLMOS, 2007).

The main families of fish parasites that cause zoonotic disease are Opisthorchiidae, Heterophyidae, Anisakidae, Gnathostomidae and Diphyllobothridae (LIMA DOS SANTOS; HOWGATE, 2011). Anisakid nematodes are common parasites of marine

\footnotetext{
*Corresponding author: Patricio Peña-Rehbein

Escuela de Medicina Veterinaria, Facultad de Recursos Naturales,

Universidad Católica de Temuco, Manuel Montt, 56, Temuco, Chile

e-mail: ppenar@uct.cl
}

organisms worldwide. Cetaceans are the final hosts of these parasites (PODOLSKA; HORBOWY, 2003). Evidence of parasites of the genera Contracaecum, Anisakis and Hysterothylacium has been found in farmed fish (CARVAJAL et al., 1995; CARVAJAL; GONZALEZ, 1990; CHEN et al., 2008; DICK et al., 1987; MARTY, 2008; MUZZALL et al., 2006; PAPERNA, 1996; SHIH et al., 2010; TORRES et al., 2010).

The presence of parasite larvae in fishes is economically important due to the increased cost of packing resulting from the need for visual inspection and the manual removal of parasites (CARVAJAL; CATTAN, 1985). These larvae are also important in public health because they are involved in diseases that are transmitted to humans (ARRIAZA et al., 2010; BROGLIA; KAPEL, 2011; CABRERA, 2010; GÓMEZ et al., 2003; HOCHBERG; HAMER, 2010; HUANG, 1988; ISHIDA et al., 2007; JOFRÉ et al., 2008; MERCADO et al., 2001; SKOV et al., 2009; MYERS, 1970; DE LA TORRE MOLINA et al., 2000; PONFERRADA et al., 2005). The species of parasites involved in these disease processes include Anisakis simplex, Pseudoterranova decipiens, Anisakis physeteris and Contracaecum spp. (DORNY et al., 2009; TORRES et al., 2000; DIAS et al., 2010). 
We studied twenty specimens of Thyrsites atun collected in the locality of Queule (39 23' 57' S and 73 $\left.{ }^{\circ} 12^{\prime} 44^{\prime \prime} \mathrm{W}\right)$, located in the coastal area of the Araucania region. All of the viscera were extracted, fixed in 96\% ethyl alcohol and stored in properly labeled containers until analysis. The samples were examined, and the number of nematodes per individual was counted at the School of Veterinary Medicine, Universidad Católica de Temuco, Chile. Parasites were found in the mesentery and serosa of the gastrointestinal tract of the fish. The pattern of randomness in the distribution of the number of parasites per host was investigated (ZAR, 1999). We used the variance/average ratio to characterize the data as randomly patterned, uniform or clustered. A second test, based on the Morisita index, was also applied for the same purpose. If both tests have values less than 1 , the data are uniformly distributed. If these values are equal to 1 , the data are random. If these values are higher than 1, the data have a grouped distribution (ZAR, 1999; FERNANDES et al., 2003). Data shown to be random by these tests tend to fit a Poisson distribution, data shown to have a grouped distribution tend to fit a negative binomial distribution, and data shown to be uniformly distributed tend to fit a binomial distribution (ZAR, 1999; FERNANDES et al., 2003).

The analysis of the data included two steps. In the first step, the pattern of the data was verified using the variance/average ratio and the Morisita index (ZAR, 1999; FERNANDES et al., 2003). In the second step, we applied the Poisson distribution, the negative binomial distribution or the binomial distribution according to the data pattern observed. We used a $\chi^{2}$ test to evaluate the fit of the data to the expected distribution (FERNANDES et al., 2003). All analyses were performed with the XLSTAT 5.0 program (Addinsoft, New York, USA).

The values of the variance/average ratio and the Morisita index were 4.30 and 37.80, respectively. These results showed that the data followed a grouped distribution. We therefore used the negative binomial distribution to model the data. The data fit this distribution $\left(\chi^{2}\right.$ Observed $=4.722<\chi^{2}$ table $=28.336$; $\mathrm{p}>0.05)$. Many individuals were found not to contain nematodes. The maximum observed number of parasites was nine per host (Table 1, Figure 1).

A previous study of the nematode Anisakis in Merluccius gayi showed no correlation between the number of parasites and the size of the host. However, that study found a correlation between the prevalence and the size of the host. This correlation is consistent with the observation that euphausiids are an intermediate host for the parasite (ANDERSON, 2000). Seasonal variation in the prevalence of $A$. simplex was not observed in Merluccius gayi. Seasonal variation in the intensity of infection with anisakids was observed in hake. This pattern was related to the behavior of the hake and the presence of alternative hosts (CARVAJAL; CATTAN, 1985). This parasite has many species as intermediate hosts, including herring, sardines and cod. This parasite can also affect humans because undercooked fish may contain the third larval stage of $A$. simplex (CHOU et al., 2011). The negative binomial distribution furnishes a robust model that allows an informative interpretation of the patterns of the number of parasites per host (SHAW et al., 1998). This conclusion is consistent with the results of this work.
Table 1. Number of parasites of the genus Anisakis observed in the mesentery and serosa of the gastrointestinal tract in Thyrsites atun (Queule, Araucania region, Chile).

\begin{tabular}{cc}
\hline $\begin{array}{c}\text { Number of } \\
\text { parasites observed }\end{array}$ & $\begin{array}{c}\text { Number of } \boldsymbol{T} \text {. atun } \\
\text { with parasites }\end{array}$ \\
\hline 0 & 12 \\
1 & 4 \\
2 & 1 \\
3 & 2 \\
4 & 0 \\
5 & 0 \\
6 & 0 \\
7 & 0 \\
8 & 0 \\
9 & 1 \\
10 & 0 \\
\hline
\end{tabular}

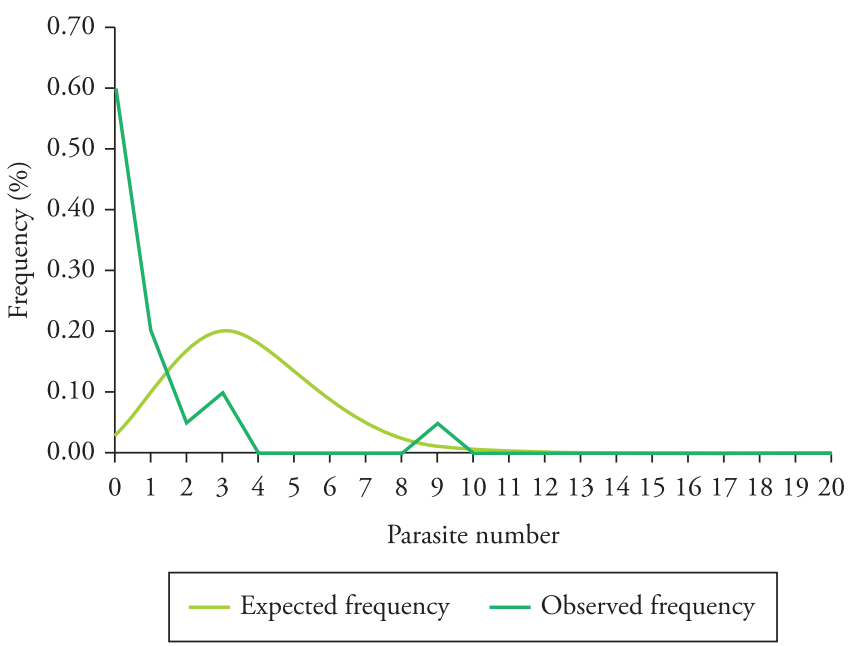

Figure 1. Expected and observed frequencies for the negative binomial distribution model of the presence of Anisakis in the mesentery and serosa of the gastrointestinal tract in Thyrsites atun (Queule, Araucania region, Chile).

This study was funded by the Veterinary Sciences School and Environmental Sciences School of the Universidad Católica de Temuco, Chile.

\section{References}

Anderson RC. Nematode parasites of vertebrates: their development and transmission. $2^{\text {nd }}$ ed. Wallingford: CAB International; 2000. 650 p. http://dx.doi.org/10.1079/9780851994215.0000

Arriaza BT, Reinhard KJ, Araújo AG, Orellana NC, Standen VG. Possible influence of the ENSO phenomenon on the pathoecology of diphyllobothriasis and anisakiasis in ancient Chinchorro populations. Mem Inst Oswaldo Cruz 2010; 105(1): 66-72. http://dx.doi.org/10.1590/ S0074-02762010000100010

Broglia A, Kapel C. Changing dietary habits in a changing world: emerging drivers for the transmission of foodborne parasitic zoonoses. Vet Parasitol 2011; 182(1): 2-13. PMid:21835548. http://dx.doi. org/10.1016/j.vetpar.2011.07.011 
Cabrera R. Anisakiasis outbreak by Anisakis simplex larvae associated to Peruvian food in Spain. Rev Esp Enferm Dig 2010; 102(10): 610-611. http://dx.doi.org/10.4321/S1130-01082010001000011

Carvajal J, Cattan PE. A study of the Anisakid infection in the Chilean Hake Merluccius gayi (Guichenot, 1848). Fish Res 1985; 3(1): 245-250. http://dx.doi.org/10.1016/0165-7836(85)90025-6

Carvajal J, Gonzalez L. Presencia de Hysterothylacium sp. (Nematoda Anisakidae) en salmón coho de Chiloé cultivado en jaulas. Rev Chil Hist Nat 1990; 63(2): 165-168.

Carvajal J, Gonzalez L, Toledo S. New record of Hysterothylacium aduncum (Rudolphi, 1802) (Nematoda: Anisakidae) in salmonids cultured in sea farms from southern Chile. Res Rev Parasitol 1995; 55: 195-197.

Chen Q, Zhang H, Song HQ, Yu HQ, Lin RQ, Zhu XQ. Prevalence of anisakid larvae in maricultured sea fish sold in Guangzhou, China. J Anim Vet Adv 2008; 7(9): 1078-1080.

Chou YY, Wang CS, Chen HG, Chen HY, Chen SN, Shih HH. Parasitism between Anisakis simplex (Nematoda: Anisakidae) third-stage larvae and the spotted mackerel Scomber australasicus with regard to the application of stock identification. Vet Parasitol 2011; 177(3-4): 324-331. PMid:21211909. http://dx.doi.org/10.1016/j.vetpar.2010.12.003

De La Torre Molina R, Pérez J, Hernández M, Jurado R, Martínez A, Morales E. Anisákiasis en pescados frescos comercializados en el norte de Córdoba. Rev Esp Salud Publica 2000; 74(5-6): 517-526. PMid:11217241.

Dias FJE, São Clemente SC, Knoff M. Nematoides anisaquídeos e cestoides Trypanorhyncha de importância em saúde pública em Aluterus monoceros (Linnaeus, 1758) no Estado do Rio de Janeiro, Brasil. Rev Bras Parasitol Vet 2010; 19(2): 94-97. PMid:20624345.

Dick TA, Papst MH, Paul HC. Rainbow trout (Salmo gairdneri) stocking and Contracecum spp. J Wildl Dis 1987; 23(2): 242-247. PMid:3586201.

Dorny P, Praet N, Deckers N, Gabriel S. Emerging food-borne parasites. Vet Parasitol 2009; 163(3): 196-206. PMid:19559535. http://dx.doi. org/10.1016/j.vetpar.2009.05.026

Duarte F, Ibáñez C, Chong J. Cambios en la morfometría bucal y su relación con la dieta de Thyrsitesatun (Euphrasen, 1791) en el centrosur de Chile. Rev Chil Hist Nat 2007; 80(4): 407-417. http://dx.doi. org/10.4067/S0716-078X2007000400002

Fernandes MG, Busoli AC, Barbosa JC. Distribuição espacial de Alabama argillacea (Hübner) (Lepidoptera: Noctuidae) em algodoeiro. Neotrop Entomol 2003; 32(1): 107-115. http://dx.doi.org/10.1590/S1519566X2003000100016

Gómez B, Lasa E, Arroabarren E, Garrido S, Anda M, Tabar AI. Allergyto Anisakis simplex. An Sist Sanit Navar 2003; 26(2): 25-30. PMid:13679960.

Hochberg NS, Hamer DH. Anisakidosis: Perils of the deep. Clin Infect Dis 2010; 51(7): 806-812. PMid:20804423. http://dx.doi. org/10.1086/656238

Huang WY. Anisakids and human anisakiasis. 2. Investigation of the anisakids of commercial fish in the district of Paris. Ann Parasitol Hum Comp 1988; 63(3): 197-208. PMid:3190121.

Ishida M, Harada A, Egawa S, Watabe S, Ebina N, Unno M. Three successive cases of enteric anisakiasis. Dig Surg 2007; 24(3): 228-231. PMid:17541267. http://dx.doi.org/10.1159/000103325
Jofré L, Neira P, Noemí I, Cerva J. Pseudoterranovosis y sushi. Rev Chil Infect 2008; 25(3): 200-206. PMid:18580998.

Lima Dos Santos C, Howgate P. Fishborne zoonotic parasites and aquaculture: A review. Aquaculture 2011; 318(3-4): 253-261. http://dx.doi.org/10.1016/j.aquaculture.2011.05.046

Marty G. Anisakid larva in the viscera of a farmed Atlantic salmon (Salmo salar). Aquaculture 2008; 279(1-4): 209-210. http://dx.doi. org/10.1016/j.aquaculture.2008.04.006

Myers BJ. Nematodes Transmitted to Man and Aquatic Mammals by Fish. J Wild Dis 1970; 6(4): 266-271. PMid:16512125.

Mercado R, Torres P, Muñoz V, Apt W. Human infection by Pseudoterranova decipiens (Nematoda, Anisakidae) in Chile: report of seven cases. Mem Inst Oswaldo Cruz 2001; 96(5): 653-655. http://dx.doi. org/10.1590/S0074-02762001000500010

Muñoz G, Olmos V. Revisión Bibliográfica de espécies ectoparásitas y hospedadoras de sistemas acuáticos de Chile. Rev Biol Mar Oceanogr 2007; 42(2): 89-148.

Muzzall PM, Eggold BT, Fahey RJ. Helminths of pond-reared walleye from Wisconsin. J Parasitol 2006; 92(2): 408-410. PMid:16729707. http://dx.doi.org/10.1645/GE-3529RN.1

Paperna I. Parasites, infections and diseases of fishes in Africa - An update. Rome: FAO; 1996. 220p.

Podolska M, Horbowy J. Infection of Baltic herring (Clupea harengus membras) with Anisakis simplex larvae, 1992-1999: a statistical analysis using generalized linear models. ICES J Mar Sci 2003; 60(1): 85-93. http://dx.doi.org/10.1006/jmsc.2002.1323

Ponferrada A, Matilla A, Borrego GM, Beceiro I, Núñez O, Lamónaca M, et al. Hemoperitoneo espontáneo secundario a yeyunoileítis por Anisakis. Rev Esp Enferm Dig 2005;97(4): 292-293.

Rodriguez L, George-Nascimento M. La fauna de parasitos metazoos Del bacalao de profundidad Dissostichus eleginoides Smitt, 1898 (Pisces: Nototheniidae) en Chile Central: Aspectos taxonómicos, ecológicos y zoogeográficos. Rev Chil Hist Nat 1996; 69(1): 21-33.

Shaw DJ, Grenfell BT, Dobson AP. Patterns of macroparasite aggregation in wildlife host populations. Parasitology 1998; 117: 597-610. PMid:9881385. http://dx.doi.org/10.1017/S0031182098003448

Shih HH, Ku CC, Wang CS. Anisakis simplex (Nematoda: Anisakidae) third-stage larval infections of marine cage cultured cobia, Rachycentron canadum L., in Taiwan. Vet Parasitol 2010; 171(3-4): 277-285. PMid:20400227. http://dx.doi.org/10.1016/j.vetpar.2010.03.023

Skov J, Kania PW, Olsen MM, Lauridsen JH, Buchmann K. Nematode infections of maricultured and wild fishes in Danish waters: A comparative study. Aquaculture 2009; 298(1-2): 24-28. http://dx.doi. org/10.1016/j.aquaculture.2009.09.024

Torres P, Moya R, Lamilla J. Nematodos anisákidos de interés en salud pública en peces comercializados en Valdivia, Chile. Arch Med Vet 2000; 32(1): 107-113. http://dx.doi.org/10.4067/S0301732X2000000100014

Torres P, Quintanilla JC, Rozas M, Miranda P, Ibarra R, San Martín MF, et al. Endohelminth parasites from salmonids in intensive culture from Southern Chile. J Parasitol 2010; 96(3): 669-670. PMid:20557217. http://dx.doi.org/10.1645/GE-2211.1

Zar JH. Biostatistical analysis. $4^{\text {nd }}$ ed. New Jersey: Prentice Hall; 1999. $663 \mathrm{p}$. 